\title{
MINAT BERWIRAUSAHA DITINJAU DARI HASIL BELAJAR PESERTA DIDIK
}

\section{ENTREPRENEURSHIP INTEREST IN TERMS OF STUDENT LEARNING OUTCOMES}

\author{
S Salwa' ${ }^{1 a}$, H Bisri ${ }^{1}$, dan A Mulyana ${ }^{1}$ \\ ${ }^{1}$ Program Studi Manajemen Pendidikan Islam, Fakultas Keguruan dan Ilmu Pendidikan, \\ Universitas Djuanda Bogor, Jl. Tol Ciawi No. 1 Kotak Pos 35 Ciawi Bogor 16720 \\ a Korespondensi: Silfy Salwa, Email: silfy.salwa@unida.ac.id \\ (Diterima: 15-11-2016; Ditelaah: 15-11-2016; Disetujui: 28-01-2017)
}

\begin{abstract}
Interest in entrepreneurship must be grown early to students or learners. Interest is a tendency to pay attention and like some things or activities, interest in something is learned and further can influence the next learning affects. In another aspect, the courage to form entrepreneurial driven by school teachers, schools that provide practical subjects can generate interest and attract students to entrepreneurship. However, based on the findings that there is not all the students have an interest in entrepreneurship. This study aims to determine whether there is influence learning outcomes entrepreneurship subjects to the interest in entrepreneurship students in SMK 1 Puncak Cisarua. This study uses a quantitative research approach, the type of associative research in the form of cause and effect. Samples used as many as 56 students out of a population of 80 students in SMK 1 Peak 2016/2017. Data collection techniques used is a graduated scale questionnaire, observation, interview and documentation. The final results of this study demonstrate the significance of the regression equation with the results and the value of F $29577 \mathrm{~F}_{\text {tabel }}$ with $\mathrm{df}_{\text {reg }}=1 \mathrm{dfres}=54$ was 4,02 at the $5 \%$ level. Thus $F_{\text {hitung }}>F_{\text {tabel }}(29577>4,02)$ so that $\mathrm{H}_{0}$ is rejected, meaning that a significant difference between the results of the study subjects entrepreneurial interest in entrepreneurship. The coefficient of determination is $0,5952=0,354$ thus the interest in entrepreneurship students $35,4 \%$ influenced by the results of learning, while $64.6 \%$ interest in entrepreneurship learning is influenced by other factors.
\end{abstract}

Keywords: entrepreneurship, entrepreneurship interests, learning outcomes.

\begin{abstract}
ABSTRAK
Minat dalam berwirausaha harus ditumbuhkan sejak dini pada pelajar atau peserta didik. Minat merupakan kecenderungan perasaan memperhatikan serta menyukai beberapa hal atau kegiatan, minat terhadap sesuatu dipelajari terlebih dahulu dan mempengaruhi belajar selanjutnya, mempengaruhi minat-minat selanjutnya. Membentuk keberanian dalam aspek lain yang didorong oleh pendidik di lembaga sekolah yang memberikan mata pelajaran yang praktis dan menarik dapat membangkitkan minat peserta didik untuk berwirausaha. Namun berdasarkan temuan yang ada belum semua peserta didik memiliki minat berwirausaha. Penelitian ini memiliki tujuan yaitu untuk mengetahui ada tidaknya pengaruh hasil belajar mata pelajaran kewirausahaan terhadap minat berwirausaha peserta didik di SMKN 1 Puncak Cisarua. Pendekatan yang digunakan pada penelitian ini yaitu pendekatan penelitian kuantitatif, jenis penelitian asosiatif berupa sebab akibat. Sampel dalam penelitian ini sebanyak 56 peserta didik dari populasi 80 peserta didik di SMKN 1 Puncak T/A 2016/2017. Teknik pengumpulan data yaitu menggunakan angket skala bertingkat, observasi, wawancara dan dokumentasi. Hasil akhir penelitian ini adalah signifikansi persamaan regresi dengan hasil nilai $F_{\text {hitung }} 29.577$ dan $\mathrm{F}_{\text {tabel }}$ dengan $\mathrm{df}_{\text {reg }}=1 \mathrm{df}_{\text {res }}=54$ adalah 4,02 pada taraf $5 \%$. Dengan demikian $\mathrm{F}_{\text {hitung }}>\mathrm{F}_{\text {tabel }}(29,577>4,02)$ sehingga $\mathrm{H}_{0}$ ditolak, artinya terdapat pengaruh yang
\end{abstract}


signifikan antara hasil belajar mata pelajaran kewirausahaan terhadap minat berwirausaha. Hasil koefisien determinasi yaitu $0,595^{2}=0,354$ dengan demikian minat berwirausaha peserta didik sebesar 35,4\% dipengaruhi oleh hasil belajar, sedangkan 64,6\% minat berwirausaha belajar dipengaruhi oleh faktor lain.

Kata kunci: hasil belajar, kewirausahaan, minat berwirausaha.

Salwa S, H Bisri, dan A Mulyana. 2017. Minat berwirausaha ditinjau dari hasil belajar peserta didik. Tadbir Muwahhid 1(1): 1-12.

\section{PENDAHULUAN}

Dewasa ini, fenomena rendahnya minat dalam berwirausaha para pemuda atau khususnya para pelajar di Indonesia masih terbilang rendah, para pelajar atau pemuda di Indonesia masih memiliki pikiran bahwa masa depan berkarir dengan mencari pekerjaan atau menjadi seorang pekerja lebih baik dibandingkan menjadi seorang pengusaha dan berwirausaha, padahal sejatinya menjadi seorang pengusaha di saat sekarang ini sangatlah menjanjikan karena lahan pekerjaan yang sedikit sedangkan pengangguran semakin banyak, maka minat dalam berwirausaha harus ditanamkan sejak dini kepada para pelajar atau peserta didik.

\section{Sekolah Menengah Kejuruan (SMK)} merupakan salah satu lembaga pendidikan yang memiliki tujuan menyiapkan peserta didiknya agar menjadi tenaga kerja yang terampil, mandiri dan memiliki kemampuan kerja. Pihak sekolah berperan penting untuk mewujudkan peserta didik yang bertanggung jawab untuk memiliki prestasi belajar yang tinggi, memiliki minat dan bakat yang akan dikembangkan dalam diri peserta didik.

Aspek lain dalam membentuk minat kewirausahaan yaitu pendidik dan lembaga pendidikan yang memberikan mata pelajaran praktis serta menarik, yang dapat membangkitkan minat peserta didik dalam berwirausaha (Alma 2011). Pengetahuan dalam berwirausaha dapat dimiliki melalui proses pendidikan atau pembelajaran disekolah. Pendidikan sebagai salah satu hal yang dinilai sangatlah penting untuk menentukan kualitas suatu bangsa. Pendidikan yaitu sebagai aktivitas yang secara sadar dirancang untuk membantu seseorang serta kelompok orang dalam mengembangkan pemikiran, pandangan hidup, sikap hidup, dan keterampilan hidup (Yustanto 2011).

Wirausahawan merupakan potensi pembangunan, menurut riset yang dikemukakan oleh Heidjrachman Ranu P dalam buku Buchori Alma, bahwa ternyata negara maju seperti negara Jepang yang keberhasilannya disponsori oleh berwirausaha tingkat kecil sebanyak 20\% dan wirausahawan yang berjumlah $2 \%$ tingkat sedang, dari jumlah penduduk di Jepang. Itulah salah satu kunci keberhasilan pembangunan yang dilakukan oleh Jepang (Alma 2011).

Kewirausahaan adalah contoh pembangunan yang nyata, jadi dapat dilihat bahwa pendidikan kewirausahaan yang diajarkan pada peserta didik sekarang ini sangatlah penting. Sedangkan faktanya kesadaran berwirausaha penduduk Indonesia ternyata masih sangat rendah artinya aspek kemandiriannya masih rendah. Bagi sebagian orang yang bekerja pada instansi swasta maupun pemerintah yang sudah merasa nyaman dengan menerima gaji rutin setiap bulan, begitupun 
kesadaran minat berwirausaha pada pelajar di Indonesia, hal ini dikemukakan dalam pemberitaan media online Vivo.co.id (Dewi 2014).

Adapun tujuan dari pendidikan kewirausahaan di sekolah yang dikemukakan oleh guru pada bidang studi kewirausahaan di SMKN 1 Puncak Cisarua adalah menumbuhkan minat berwirausaha pada peserta didik, yang dapat dilihat melalui hasil belajar yang diperoleh peserta didik saat mengikuti pembelajaran kewirausahaan di sekolah. Hasil belajar tersebut bisa dilihat melalui hasil penilaian pembelajaran pada mata pelajaran kewirausahaan.

Upaya untuk menumbuhkan kewirausahaan di SMKN 1 Puncak Cisarua masih terhalang beberapa kendala diantaranya yaitu anggapan bahwa sebagian peserta didik yang mengatakan bahwa berwirausaha hanya sebagai profesi berdagang, bukan profesi yang tinggi sehingga muncul rasa malu dan malas ketika melakukan praktik kewirausahaan pada mata pelajaran kewirausahaan, sehingga terdapat hal yang memunculkan bahwa minat berwirausaha di SMKN 1 Puncak Cisarua terbilang rendah, alasan tersebut menjadi dasar dan menggugah peneliti untuk melakukan penelitian mengenai "Pengaruh Hasil Belajar Kewirausahaan Terhadap Minat Berwirausaha Peserta Didik".

\section{MATERI DAN METODE}

\section{Materi}

\section{Hasil Belajar Kewirausahaan}

Hasil belajar yaitu seluruh kompetensi yang dimiliki peserta didik, sebagai akibat dari kegiatan belajar yang dilakukannya. Hasil pembelajaran merupakan nilai-nilai, pengertian-pengertian, pola-pola perbuatan, dan sikap-sikap serta dapat disimpulkan bahwa hasil belajar yaitu perubahan tingkah laku dari peserta didik secara nyata setelah melakukan proses belajar mengajar yang sesuai dengan pengajaran (Sutanto 2014).

Hasil belajar meliputi pemahaman konsep (aspek kognitif), sikap peserta didik (aspek afektif), dan keterampilan proses (aspek psikomotorik). adapun jenis-jenis hasil belajar adalah, hasil belajar pemahaman konsep (Kognitif) diartikan sebagai kemampuan untuk menyerap arti dari materi atau bahan yang dipelajari. Hasil belajar sikap (Afektif) tidak hanya merupakan aspek mental semata, melainkan mencakup pula dengan aspek respon fisik, dalam sikap harus ada kekompakan antara mental dan fisik secara serempak maupun objek-objek tertentu. Sikap merujuk pada perbuatan, prilaku, atau tindakan seseorang. Sedangkan hasil belajar keterampilan proses (Psikomotorik) adalah kemampuan keterampilan yang mengarah terhadap pembangunan kemampuan mental, fisik, serta sosial yang mendasar sebagai penggerakkan kemampuan yang lebih tinggi pada diri individu peserta didik. (Siregar dkk 2014).

Untuk mengetahui apakah hasil belajar yang dicapai telah sesuai dengan tujuan yang dikehendaki maka perlu dilakukan evaluasi atau penilaian yang merupakan tindak lanjut atau cara untuk mengukur tingkat penugasan siswa. Kemajuan prestasi peserta didik tidak saja diukur dari tingkat penugasan ilmu pengetahuan tetapi juga sikap dan keterampilan. Dengan demikian penilaian hasil belajar siswa mencakup segala hal yang dapat dipelajari disekolah, baik itu menyangkut pengetahuan, sikap dan keterampilan.

Mata pelajaran kewirausahaan yang diperbaharui menjadi pelajaran Prakarya 
dan Kewirausahaan dalam Kurikulum 2013, merupakan salah satu mata pelajaran yang dimasukkan dalam kurikulum Sekolah Menengah Kejuruan (SMK), dalam mata pelajaran kewirausahaan tersebut juga ada potensi prakarya yang diharapkan agar lulusan SMK tidak hanya siap untuk bekerja dalam lapangan kerja yang ada, namun juga mampu menciptakan lapangan kerja.

Faktor yang mempengaruhi hasil belajar yang pertama adalah faktor internal merupakan faktor yang bersumber dari dalam diri peserta didik, yang mempengaruhi kemampuan belajarnya. Faktor ini meliputi, kecerdasan, minat perhatian, motivasi belajar, ketekunan, sikap, kebiasaan belajar, serta kondisi fisik dan kesehatan.

Faktor yang kedua yaitu Faktor eksternal adalah faktor yang berasal dari luar diri peserta didik yang mempengaruhi hasil belajar yaitu, keluarga, sekolah, dan masyarakat.

Penilaian hasil belajar dapat dibagi dua, yakni penilaian formatif dan penilaian sumatif. Penilaian formatif dilakukan untuk memantau sejauh mana suatu proses pendidikan telah berjalan sebagaimana yang telah direncanakan. Sedangkan penilaian sumatif dilakukan untuk mengetahui sejauh mana peserta didik dapat berpindah dari suatu unit ke unit berikutnya. Instrumen evaluasi yang digunakan dalam penilaian hasil belajar dapat berupa instrumen test (pre test, post test, test tertulis, lisan atau perbuatan) maupun non test seperti observasi, skala rating dan lain-lain.

\section{Minat Berwirausaha Peserta didik}

Dalam Islam anak terlahir dalam keadaan fitrah (suci) dan memiliki potensi, seperti akal, hati dan pendengaran. Melalui hati anak memiliki perasaan, dari perasaan tersebutlah minat muncul dalam diri seseorang setelah tumbuh menjadi besar dan dewasa melalui proses belajar. Islam menganggap pentingnya peran orang tua atau keluarga sebagai pendidik pertama yang mengarahkannya. Minat dan bakat termasuk kedalam fitrah anak dalam Islam.

Minat anak dalam Islam perlu diarahkan agar tidak terjadi penyimpangan dan berlawanan dengan ajaran Islam. Minat adalah perasaan yang muncul dalam diri seseorang atas dorongan dan kemauan diri sendiri untuk menyukai suatu hal, minat akan muncul pada diri seseorang apabila seseorang tersebut telah melakukan pelatihan dan melalui proses belajar terlebih dahulu. Minat disini berpengaruh terhadap keinginan untuk memiliki usaha sendiri.

Wirausaha adalah seorang pembuat keputusan yang membantu sistem perekonomian. Pendidikan atau lembaga sekolah formal menjadi tempat yang sangat strategis untuk menumbuhkan bakat wirausaha, sebab sekolah adalah lembaga pendidikan yang sangat dipercaya masyarakat untuk masa depan yang lebih baik.

Kewirausahaan dapat didefinisikan secara ringkas sebagai suatu kemampuan kreatif dan inovatif (creat new and different) yang dijadikan kiat, dasar, sumber daya, proses, dan perjuangan untuk menciptakan nilai tambah barang dan jasa yang dilakukan dengan keberanian untuk menghadapi resiko

Ilmu kewirausahaan adalah suatu disiplin ilmu yang mempelajari tentang nilai, kemampuan, ability, dan prilaku seseorang dalam menghadapi tantangan hidup untuk memperoleh peluang dengan berbagai resiko yang mungkin dihadapinya.

Minat berwirausaha adalah kecenderungan hati dalam diri untuk tertarik menciptakan suatu usaha yang 
kemudian mengorganisir, mengatur, menanggung resiko dan mengembangkan usaha yang diciptakannya tersebut. Minat berwirausaha berasal dari dalam diri seseorang untuk menciptakan sebuah bidang usaha. Minat berwirausaha pada peserta didik diantaranya keinginan, ketertarikan serta kesediaan seseorang untuk bekerja keras atau kemauaan yang keras dengan adanya pemusatan perhatian dalam berwirausaha untuk memenuhi kebutuhan hidupnya secara mandiri (Wahyuni 2015).

Faktor yang mempengaruhi minat berwirausaha diantaranya faktor internal yaitu faktor yang berasal dari dalam diri individu yang bersangkutan, misalnya karakter, pengalaman sikap, motif dan persepsi. Faktor eksternal yaitu faktor yang berasal dari luar misalnya lingkungan fisik, lingkungan keluarga, lingkungan sekolah dan lingkungan masyarakat.

\section{Metode}

\section{Metode Penelitian}

Penelitian ini menggunakan pendekatan penelitian kuantitatif, artinya penelitian yang ditujukan untuk menjawab permasalahan-permasalahan yang diteliti melalui teknik pengukuran yang tepat terhadap variabel tertentu, sehingga selanjutnya menghasilkan simpulansimpulan yang dapat digeneralisasikan. Penelitian ini memiliki sifat korelasi kausal yang bertujuan untuk mengetahui pengaruh variabel X (Hasil Belajar Kewirausahaan) terhadap variabel Y (Minat Berwirausaha Peserta didik ).

\section{Lokasi Penelitian}

Penelitian dilaksanakan di SMKN 1 Puncak Cisarua, yang berada di Jl. Raya Puncak, Km 86. No 24, Desa Tugu Selatan, Kecamatan
Cisarua, Kabupaten Bogor, Jawa Barat 16750. Populasi yang menjadi objek penelitian ini adalah seluruh peserta didik kelas X SMKN 1 Puncak Cisarua tahun ajaran 2016/2017 yang berjumlah 80 orang peserta didik. pengambilan sampel menggunakan rumus slovin, margin error pada sampel penelitian ini sebesar $7,3 \%$ dari 80 populasi menjadi 56 sampel yang diambil.

\section{Teknik Pengumpulan Data}

Teknik pengumpulan data menggunakan angket, skala bertingkat, observasi, wawancara dan dokumentasi.

\section{Dokumentasi}

Dalam mengumpulkan data pada variabel hasil belajar kewirausahaan, peneliti menggunakan instrumen pedoman dokumentasi, berupa data nilai raport peserta didik pada semeseter ganjil tahun ajaran 2016-2017, yang merupakan hasil belajar peserta didik kelas X SMKN 1 Puncak Cisarua pada mata pelajaran kewirausahaan. Dari nilai raport inilah peneliti akan mendapatkan data yang jelas mengenai variabel $\mathrm{X}$ yaitu hasil belajar mata pelajaran kewirausahaan, dari nilai tersebut pula peneliti mendapatkan informasi mengenai identitas peserta didik. Metode dokumentasi digunakan untuk mengidentifikasi kecenderungan dalam penelitian dan praktek mengenai suatu fenomena dalam suatu bidang. Partisipan penelitian mencatat semua kejadian yang diteliti dalam catatan harian atau jurnal, peneliti kemudian melakukan analisis konten terhadap hasil-hasil kajian, laporanlaporan maupun catatan-catatan penelitian.

\section{Skala Rate}

Dalam mengumpulkan data variabel minat berwirausaha peneliti menggunakan rating scale atau skala rating yaitu data yang diperoleh semuanya adalah data kualitatif 
yang kemudian dikuantitatifkan. Tetapi dengan rating-scale data mentah yang diperoleh berupa angka kemudian ditafsirkan dalam pengertian kualitatif. Rating scale ini lebih fleksibel, tidak terbatas untuk pengukuran sikap saja tetapi untuk mengukur persepsi responden terhadap fenomena lainnya, seperti skala untuk mengukur status sosial ekonomi, kelembagaan, pengetahuan, kemauan, proses kegiatan dan lain-lain.

\section{Contoh 1:}

Seberapa tinggi pengetahuan anda terhadap mata pelajaran berikut sebelum dan sesudah mengikuti pendidikan dan latihan?

$0=$ bila sama sekali tidak tahu

$1=$ telah mengetahui sampai dengan $25 \%$

$2=$ telah mengetaui sampai dengan $50 \%$

$3=$ telah mengetaui sampai dengan $75 \%$

4= telah mengetaui sampai $100 \%$

\section{Wawancara}

Wawancara merupakan suatu instrumen yang digunakan peneliti untuk mendapatkan data dan informasi secara lisan. Wawancara hendaknya dilaksanakan secara mendalam guna mendapatkan informasi yang jelas dan valid.

Wawancara dalam penelitian ini yaitu peneliti melakukan wawancara kepada bagian tata usaha untuk mencari informasi siapa yang dapat dijadikan objek penelitian, lalu setelah itu melakukan wawancara kedua yaitu kepada guru mata pelajaran kewirausahaan kepada Bapak Lingga, untuk mengetahui bagaimana hasil belajar peserta didik pada mata pelajaran kewirausahaan peserta diidk di SMKN 1 Puncak Cisarua dan mengetahui bagaimana minat berwirausaha peserta didik setelah menerima pembelajaran pada mata pelajaran kewirausahaan.

\section{Observasi}

Observasi adalah pengamatan serta pencatatan yang dilakukan peneliti secara sistematis terhadap gejala-gejala yang terlihat pada objek penelitian. Dalam penelitian ini peneliti melakukan penelitian langsung terhadap peserta didik di SMKN 1 Puncak Cisarua.

\section{Teknik Analisis Data}

Teknik analisis data dalam penelitian ini menggunakan analisis regresi, yang digunakan untuk mengetahui bagaimana antar variabel saling berhubungan (Arifin 2012).

\section{HASIL DAN PEMBAHASAN}

\section{Hasil}

\section{Profil SMKN 1 Cisarua}

SMKN 1 Puncak Cisarua adalah lembaga pendidikan negeri yang terletak di Jalan Raya Puncak Km. 86 No. 24, Desa Tugu Selatan, Kecamatan Cisarua, Kabupaten Bogor, Jawa Barat, kode pos 16750. SMK Negeri pertama yang berada di Kecamatan Cisarua, didirikan pada tahun 2012 oleh Bupati Kabupaten Bogor yang terakreditasi A, SMKN 1 Puncak Cisarua memiliki luas tanah $12671 \mathrm{~m}^{2}$ dan luas bangunan sekolah $1267 \mathrm{~m}$.

SMKN 1 Puncak Cisarua Bogor memiliki dua jurusan yaitu jurusan akomodasi perhotelan, dan jurusan jasa boga. Adapun visi SMKN 1 Puncak Cisarua yaitu "Menghasilkan lulusan yang kompeten, inovatif, dan kompetitif di bidang pariwisata berlandaskan iman dan taqwa", sedangkan Misi SMKN 1 Puncak Cisarua yaitu "Menyiapkan peserta didik yang beriman dan bertaqwa, melalui penerapan manajemen berbasis sekolah secara optimal dengan melibatkan seluruh warga sekolah dan 
penentu kebijakan sekolah yang menekankan pada daya saing di era pasar bebas".

\section{Data Hasil Belajar Kewirausahaan}

Data mengenai hasil belajar peserta didik yang diambil sampel sebanyak 56 peserta didik kelas X pada jurusan APH 1, APH 2, APH 3, dan X Jasa Boga pada mata pelajaran kewirausahaan diperoleh melalui dokumentasi nilai raport peserta didik kelas $\mathrm{X}$ pada tahun ajaran 2016-2017 yang mencakup nilai pengetahuan dan keterampilan.

Sebelum itu, nilai pengetahuan dan keterampilan pada raport 2013 menjadi 2 nilai yang berbeda untuk memperoleh data yang akan dimasukan dalam deskripsi frekuensi, maka peneliti mengolah nilai pengetahuan dan keterampilan menjadi satu nilai dan diambil hasilnya dengan data deskripsi frekuensi.

Hasil deskriftif data statistik pada variabel hasil belajar adalah, terdapat hasil skor tertinggi 84 , skor terendah 65 , rata-rata75,5, standar devisi 4,45 , median 76 , dan modus 75. Untuk mengetahui persentase nilai hasil belajar peserta didik kelas $\mathrm{X}$ pada mata pelajaran kewirausahaan di SMKN 1 Puncak Cisarua Bogor, maka dilakukan pengkategorian yaitu, rendah, sedang dan tinggi, yang akan disajikan pada grafik (Gambar 1).

Pada Gambar 1 dapat dilihat bahwa nilai hasil belajar yang tinggi berada pada $25,10 \%$, nilai hasil belajar sedang atau sudah mencapai KKM berada pada 64,30\% dan nilai hasil belajar yang rendah mencapai 10,60\%. Dengan demikian nilai hasil belajar mata pelajaran kewirausahaan di SMKN 1 Puncak Cisarua Bogor, sudah baik karena berada pada kategori sedang.

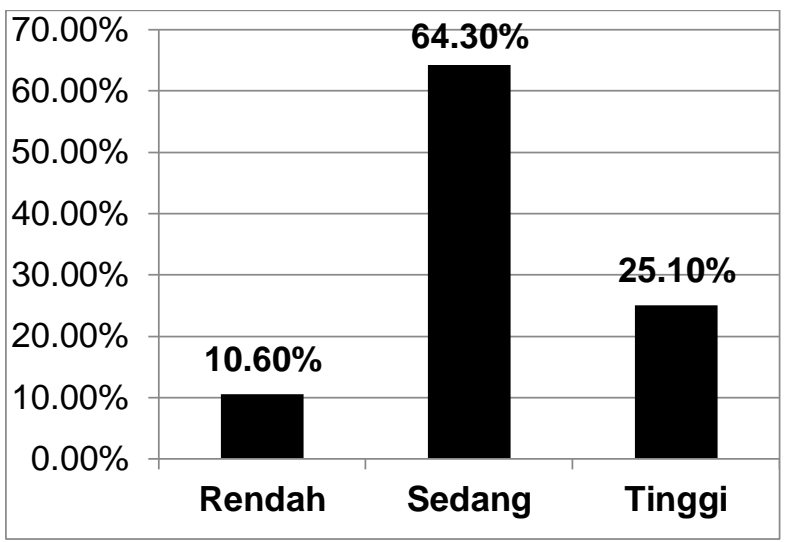

Gambar 1 Persentase nilai hasil belajar

\section{Data Minat berwirausaha}

Data variabel minat berwirausaha diperoleh melalui angket berupa skala bertingkat yang dibagikan kepada 56 responden atau sampel pada kelas X di SMKN 1 Puncak Cisarua Bogor, dengan jumlah 17 butir pernyataan. Skor yang digunakan dalam skala tersebut adalah 5-1, diperoleh skor minat berwirausaha peserta didik.

Dari deskiripsi frekuensi minat berwirausaha diperoleh skor terendah 60, skor tertinggi 80 rata-rata sebesar 74.5, mean 70.71, median 72 , modus 74 , standar deviasi 5,17. Untuk mengetahui persentase minat berwirausaha peserta didik kelas $\mathrm{X}$ pada mata pelajaran kewirausahaan di SMKN 1 Puncak Cisarua Bogor, maka dilakukan pengkategorian yaitu, rendah, sedang dan tinggi.

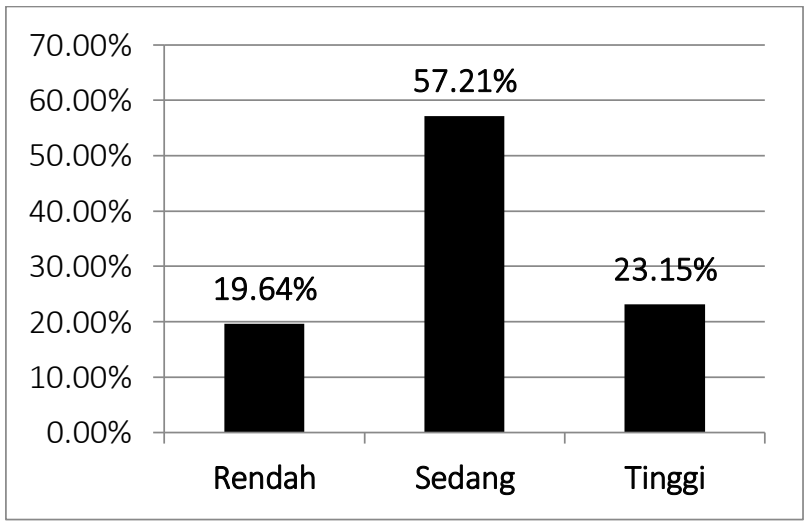

Gambar 2 Persentase minat berwirausaha 


\section{Uji Prasyarat Analisis Data}

Uji prasyarat analisis data yang akan dilakukan adalah uji normalitas dan linieritas. Uji normalitas yang dilakukan pada penelitian ini adalah uji Chi Kuadrat dengan keputusan pengujian:

Jika $X^{2}$ hitung $<X^{2}$ tabel terima $\mathrm{H}_{0}$ dan jika $X^{2}$ hitung $>X^{2}$ tabel tolak $\mathrm{H}_{0}$.

\section{Uji Chi-Kuadrat Hasil Belajar Kewirausahaan}

Pada Tabel 1 terdapat nilai $X^{2}$ hitung 42,386 dan $x^{2}$ tabel 12,592 maka 42,386 >12,592, artinya $\mathrm{H}_{0}$ ditolak berarti data hasil belajar mata pelajaran kewirausahaan berdistribusi normal.

Tabel 1 Chi-kuadrat hasil belajar kewirausahaan

\begin{tabular}{lr}
\hline & Hasil Belajar \\
\hline 2 & $42.286^{\mathrm{a}}$ \\
Df & 15 \\
Asymp. Sig. & .000 \\
\hline
\end{tabular}

\section{Uji Chi-Kuadrat Minat Berwirausaha}

Pada Tabel 2 terdapat nilai $X^{2}$ hitung 24,143 dan $x^{2}$ tabel 12,592 maka 24,143>12,592, artinya $\mathrm{H}_{0}$ ditolak berarti data minat berwirausaha berdistribusi normal.

Tabel 2 Chi-Kuadrat minat berwirausaha

\begin{tabular}{lr}
\hline & Minat_Berwirausaha \\
\hline Chi-Square & $24.143 \mathrm{a}$ \\
Df & 16 \\
Asymp. Sig. & .086 \\
\hline
\end{tabular}

\section{Uji Hipotesis}

Pengujian hipotesis dalam penelitian ini bertujuan untuk membuktikan ada atau tidak ada pengaruh antara hasil belajar mata pelajaran kewirausahaan dengan minat berwirausaha yang meliputi, korelasi product moment, persamaan regresi, mencari signifikansi persamaan regresi dan koefisien determinasi.

\section{Korelasi Product Moment}

Pengujian analisis yang pertama menggunakan korelasi product moment (pearson) dengan dasar pengambilan keputusan jika nilai signifikansi $<0.05$ sebaliknya jika nilai signifikansi $>0.05$ maka tidak terdapat korelasi. Berikutnya berdasarkan tanda bintang $\quad\left({ }^{*}\right)$ yang diberikan SPSS, jika terdapat tanda $(*)$ maka antar variabel yang dianalisis terjadi korelasi, maka terdapat korelasi sebaliknya jika tidak ada tanda $(*)$ maka tidak terdapat korelasi.

Tabel 3 Korelasi product moment

\begin{tabular}{|c|c|c|c|}
\hline & & $\begin{array}{c}\text { Hasil } \\
\text { Belajar }\end{array}$ & $\begin{array}{c}\text { Minat } \\
\text { Berwirausaha }\end{array}$ \\
\hline \multirow[t]{3}{*}{ Hasil Belajar } & $\begin{array}{l}\text { Pearson } \\
\text { Correlation }\end{array}$ & 1 & $.595^{* *}$ \\
\hline & $\begin{array}{l}\text { Sig. } \\
\text { (2-tailed) }\end{array}$ & & .000 \\
\hline & $\mathrm{N}$ & 56 & 56 \\
\hline \multirow[t]{3}{*}{$\begin{array}{l}\text { Minat } \\
\text { Berwirausaha }\end{array}$} & $\begin{array}{l}\text { Pearson } \\
\text { Correlation }\end{array}$ & $.595^{* *}$ & 1 \\
\hline & $\begin{array}{l}\text { Sig. } \\
\text { (2-tailed) }\end{array}$ & .000 & \\
\hline & $\mathrm{N}$ & 56 & 56 \\
\hline
\end{tabular}

Keterangan: ${ }^{* *}$. Correlation is significant at the 0.01 level (2-tailed).

Dalam Tabel 3 diketahui berdasarkan nilai signifikansi sebesar 0.000 dan nilai $F_{\text {tabel }}$ 0.05 , maka antara nilai signifikansi $0,000<$ 0,05 yang artinya terdapat korelasi antara nilai hasil belajar kewirausahaan dan minat berwirausaha. Berdasarkan tanda $(*)$ yang diberikan oleh program SPSS pada nilai $0,595^{* *}$ maka terdapat korelasi antara hasil belajar mata pelajaran kewirausahaan dengan minat berwirausaha peserta didik. 


\section{Persamaan Regresi}

Analisis regresi yang digunakan dalam penelitian ini adalah analisis regresi sederhana, yang bertujuan untuk mengetahui bagaimana pengaruh hasil belajar mata pelajaran kewirausahaan terhadap minat berwirausaha yang akan disajikan pada Tabel 4 .

Tabel 4 Persamaan regresi

\begin{tabular}{|c|c|c|c|c|c|}
\hline \multirow{2}{*}{ Model } & \multicolumn{2}{|c|}{$\begin{array}{c}\text { Unstandardized } \\
\text { Coefficients }\end{array}$} & \multirow{2}{*}{$\begin{array}{c}\begin{array}{c}\text { Standardized } \\
\text { Coefficients }\end{array} \\
\text { Beta }\end{array}$} & \multirow{2}{*}{\multicolumn{2}{|c|}{ T Sig. }} \\
\hline & B & $\begin{array}{l}\text { Std. } \\
\text { Error }\end{array}$ & & & \\
\hline 1 (Constant) & 18.070 & 9.696 & & 1.864 & .068 \\
\hline Hasil Belajar & .690 & .127 & .595 & 5.439 & .000 \\
\hline
\end{tabular}

Keterangan: a. Dependent Variable: Minat Berwirausaha

Karena nilai koefisien a dan b bertanda positif 0,690 dapat dikatakan hubungan antara hasil belajar mata pelajaran kewirausahaan dengan minat berwirausaha merupakan hubungan yang berbanding lurus. Artinya semakin tinggi hasil belajar, semakin tinggi pula minat berwirausaha peserta didik. Adapun hasil dari persamaan regresi adalah:

$$
\hat{\mathrm{Y}}=18,070+0,690 \mathrm{X}
$$

\section{Signifikansi Persamaan Regresi}

Pengujian hipotesis selanjutnya yaitu mencari persamaan regresi dengan keputusan hipotesis sebagai berikut:

$\mathrm{H}_{0}: \beta=0$ (koefisien regresi tidak berarti)

$\mathrm{H}_{1}: \beta \neq 0$ (koefisien regresi berarti)

Dengan kriteria pengujian:

Terima $\mathrm{H}_{0}$ jika $\mathrm{F}_{\mathrm{h}}<\mathrm{F}_{\mathrm{t}}$

Tolak $\mathrm{H}_{0}$ jika $\mathrm{F}_{\mathrm{h}}>\mathrm{F}_{\mathrm{t}}$

Pada Tabel 5 diperoleh nilai Fhitung 29.577 dan $\mathrm{F}_{\text {tabel }}$ dengan $\mathrm{df}_{\mathrm{reg}}=1 \mathrm{df}_{\text {res }}=54$ adalah 4,02 pada taraf $5 \%$. Dengan demikian $F_{\text {hitung }}>F_{\text {tabel }}$
(29.577 > 4,10) sehingga $\mathrm{H}_{0}$ ditolak, artinya terdapat pengaruh yang signifikan antara hasil belajar mata pelajaran kewirausahaan terhadap minat berwirausaha.

Tabel 5 Signifikansi persamaan regresi

\begin{tabular}{lrrrcc}
\hline \multicolumn{1}{c}{ Model } & $\begin{array}{c}\text { Sum of } \\
\text { Squares }\end{array}$ & Df & $\begin{array}{c}\text { Mean } \\
\text { Square }\end{array}$ & F & Sig. \\
\hline Regression & 520.727 & 1 & 520.727 & 29.577 & $.000^{a}$ \\
Residual & 950.701 & 54 & 17.606 & & \\
Total & 1471.429 & 55 & & & \\
\hline
\end{tabular}

Keterangan: a.Predictors: (Constant) Hasil Belajar; b.Dependent Variable: Minat Berwirausaha.

\section{Koefisien Determinasi}

Pengujian hipotesis yang yang terakhir yaitu menentukan koefisien determinasi, artinya mencari tahu seberapa besar koefisien determinasi hasil belajar mata pelajaran kewirausahaan yang mempengaruhi minat berwirausaha, adapun hasil koefisien determinasi dalam penelitian ini terdapat pada Tabel 6.

Tabel 6 Koefisien determinasi

\begin{tabular}{lllll}
\hline Model & $R$ & RSquare & $\begin{array}{l}\text { Adjusted } \\
\text { RSquare }\end{array}$ & $\begin{array}{l}\text { Std. Error of } \\
\text { the Estimate }\end{array}$ \\
\hline 1 & $.595^{\mathrm{a}}$ & .354 & .342 & 4.19590 \\
\hline \hline
\end{tabular}

Keterangan: a. Predictors: (Constant), Hasil Belajar; $b$. Dependent Variable: Minat Berwirausaha

Berdasarkan Tabel 6, diperoleh korelasi antara hasil belajar kewirausahaan dan minat berwirausaha adalah 0,595 artinya terdapat hubungan yang positif dan signifikan sebesar 0,595 antara hasil belajar kewirausahaan dan minat berwirausaha namun pengaruh yang diberikan bernilai kecil. Koefisien determinasi yaitu 0,5952 = 0,354 dengan demikian minat berwirausaha peserta didik sebesar 35,4\% dipengaruhi oleh hasil belajar, sedangkan 64,6\% minat berwirausaha belajar dipengaruhi oleh faktor lain. 


\section{Pembahasan}

Berdasarkan analisis data yang telah dilakukan maka terdapat hasil dari penelitian yaitu pada deskriptif data sudah dapat diketahui data nilai hasil belajar kewirausahaan pada T/A 2016/2017 dan minat berwirausaha yaitu, terdapat skor tertinggi 84 , skor terendah 65 , rata-rata 75,5 , standar devisi 4,45, median 76, dan modus 75. Data minat berwirausaha diperoleh skor terendah 60 , skor tertinggi 80 rata-rata sebesar 74,5, median 72 , modus 74 , standar deviasi 5,17. Adapun persentase antara hasil belajar dan minat berwirausaha sama-sama berada pada kategori sedang yang artinya baik yaitu hasil belajar $64,30 \%$ dan minat berwirausaha $57,21 \%$.

Pada pengujian prasyarat analisis data yang pertama dilakukan uji normalitas, dengan jenis pengujian uji chi-kuadrat atau uji chi-square adapun hasil data pada uji chikuadrat hasil belajar kewirausahaan $42,386>12,592$, artinya $\mathrm{H}_{0}$ ditolak berarti data hasil belajar mata pelajaran kewirausahaan berdistribusi normal. Uji chikuadrat yang kedua pada data minat berwirausaha dengan hasil 24,143 >12,592, artinya $\mathrm{H}_{0}$ ditolak berarti data hasil belajar mata pelajaran kewirausahaan berdistribusi normal.

Pengujian prsayarat analisis data yang selanjutnya adalah uji linier dengan melihat

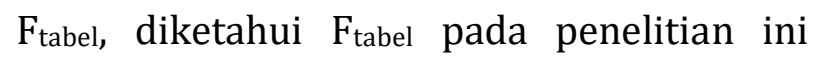
adalah 4,03 dan Fhitung 1,56. Maka Fhitung lebih kecil dari pada $F_{\text {tabel, }}$ yang artinya terdapat hubungan yang linier antara hasil belajar dan minat berwirausaha.

Pengujian analisis data penelitian selanjutnya yaitu pengujian hipotesis, yang pertama dengan menggunakan product moment untuk mengetahui ada tidaknya hubungan antara variabel hasil belajar kewirausahaan terhadap variabel minat berwirausaha dengan hasil nilai signifikansi $0,000<0,05$ yang artinya terdapat korelasi antara variabel X dan Y. Berdasarkan tanda ${ }^{*}$ ) yang diberikan oleh program SPSS pada nilai $0,595^{* *}$ maka terdapat korelasi antara variabel X hasil belajar mata pelajaran kewirausahaan dengan minat berwirausaha peserta didik.

Pengujian hipotesis dengan menggunakan rumus regresi linier yang pertama persamaan regresi dengan hasil $\mathrm{Y}=$ 18.070+0,690 X karena nilai koefisien (b) bertanda positif 0,690 dapat dikatakan hubungan antara hasil belajar mata pelajaran kewirausahaan dengan minat berwirausaha merupakan hubungan yang berbanding lurus. Artinya semakin tinggi hasil belajar, semakin tinggi pula minat berwirausaha peserta didik.

Pengujian hipotesis dengan menentukan signifikansi persamaan regresi dengan hasil nilai $F_{\text {hitung }} 29.577$ dan $\mathrm{F}_{\text {tabel }}$ dengan $\mathrm{df}_{\text {reg }}=1$ $\mathrm{df}_{\text {res }}=54$ adalah 4,02 pada taraf 5\%. Dengan demikian $F_{\text {hitung }}>F_{\text {tabel }}(29.577>4,10)$ sehingga $\mathrm{H}_{0}$ ditolak, artinya terdapat pengaruh yang signifikan antara hasil belajar mata pelajaran kewirausahaan terhadap minat berwirausaha.

Pengujian hipotesis yang terakhir yaitu menentukan koefisien determinasi yang bertujuan untuk mengetahui seberapa persen pengaruh hasil belajar kewirausahaan terhadap minat berwirausaha dengan hasil koefisien determinasi yaitu $0,595^{2}=0,354$ dengan demikian minat berwirausaha peserta didik sebesar 35,4\% dipengaruhi oleh hasil belajar, sedangkan $64,6 \%$ minat berwirausaha peserta didik dipengaruhi oleh faktor lain.

Pengaruh yang diberikan hasil mata pelajaran kewirausahaan terhadap minat berwirausaha disini termasuk pengaruh yang berkategori rendah sebab pengaruh 
yang diberikan hanya $34,5 \%$ hal ini dapat dilihat dari pengakuan peserta didik di SMKN 1 Puncak Cisarua, yang sudah peneliti observasi melalui wawancara, mereka mengatakan bahwa senang dengan adanya mata pelajaran kewirausahaan, namun bagi mereka mata pelajaran kewirausahaan dianggap sebagai mata pelajaran yang tergolong sulit, dan cara pendidik menyampaikan pembelajaran mata pelajaran kewirausahaan tersebut masih belum dapat menarik perhatian khususnya peserta didik, sehingga berpengaruh besar pada hasil belajar mata pelajaran kewirausahaan yang diperoleh terbanyak hanya ada pada kategori sedang bukan tinggi.

\section{KESIMPULAN DAN IMPLIKASI}

\section{Kesimpulan}

Berdasarkan hasil penelitian mengenai minat berwirausaha di tinjau dari hasil belajar peserta didik yang telah dilakukan maka terdapat kesimpulan bahwa Persamaan regresi pada penelitian dengan indeks korelasi 0,595 dan nilai signifikan sebesar 0.000 dan nilai $F_{\text {tabel }} 0.05$, maka antara nilai signifikansi $0,000<0,05$ yang artinya terdapat korelasi antara variabel $\mathrm{X}$ dan Y. Berdasarkan pengujian korelasi dengan product moment terdapat korelasi antara hasil belajar kewirausahaan dengan minat berwirausaha peserta didik.

Pada persamaan regresi $\hat{Y}=18,070+0,690$ $\mathrm{X}$ dikatakan hubungan antara hasil belajar kewirausahaan dengan minat berwirausaha peserta didik merupakan hubungan yang berbanding lurus. Artinya semakin tinggi hasil belajar, semakin tinggi pula minat berwirausaha.

Terdapat pengaruh yang signifikan antara hasil belajar kewirausahaan terhadap minat berwirausaha dengan $F_{\text {hitung }} 29.577$ dan $F_{\text {tabel }}$ dengan $\mathrm{df}_{\text {reg }}=1 \mathrm{df}_{\text {res }}=54$ adalah 4,02 pada taraf 5\%. Dengan demikian $F_{\text {hitung }}>F_{\text {tabel }}$ $29.577>4,10$ sehingga $\mathrm{H}_{0}$ ditolak.

Besar koefisien determinasi atau R Square 0,354 artinya minat berwirausaha peserta didik sebesar 35,4\% dipengaruhi oleh hasil belajar, sedangkan $64,6 \%$ minat berwirausaha belajar dipengaruhi oleh faktor lain.

\section{Implikasi}

Mata pelajaran kewirausahaan harus dapat memberikan pelajaran yang bisa meningkatkan hasil belajar peserta didik, serta meningkatkan pembelajaran kewirausahaan agar lebih disukai dan menarik peserta didik. Dalam evaluasi pembelajaran, guru mata pelajaran kewirausahaan perlu memperhatikan kembali apa yang menyebabkan nilai peserta didik belum mencapai prestasi yang tinggi atau perlu ada perhatian khusus pada peserta didik yang hasil belajarnya rendah.

Peserta didik harus dapat meningkatkan pengetahuan dan tekun dalam pembelajaran kewirausahaan agar hasil belajar pada mata pelajaran kewirausahaannya dapat meningkat dan lebih baik. Minat berwirausaha peserta didik juga harus lebih ditingkatkan kembali karena minat berwirausaha dapat memberikan manfaat bagi kehidupan seseorang untuk perubahan masa depan yang lebih baik, mengingat lahan pekerjaan yang sulit didapat maka nilai lebih yang dapat dimiliki oleh setiap orang salah satunya yaitu aspek kewirausahaan.

Bagi SMKN 1 Puncak Cisarua, agar dapat menerapkan kebijakan-kebijakan guna meningkatkan minat berwirausaha peserta didik, salah satunya lebih memperhatikan serta manambah fasilitas mengenai aspek kewirausahaan di sekolah baik melalui aspek pengetahuan, psikomotorik dan afektifnya. 
Sehingga diharapkan hasil belajar kewirausahaan semakin baik dan minat berwirausahapun semakin meningkat.

\section{DAFTAR PUSTAKA}

Alma B. 2011. Kewirausahaan untuk mahasiswa dan umum. Alfabeta, Bandung.

Arifin Z. 2012. Penelitian pendidikan: metode dan paradigma baru. Remaja Rosdakarya, Bandung.

Darmawan H. 2016. Pengaruh praktik kerja industri dan prestasi kewirausahaan terhadap minat berwirausaha. Jurnal Pendidikan Teknik Otomotif. Volume 07 Nomor 01.

Djaali. 2015. Psikologi pendidikan. Bumi Aksara, Jakarta.
Slameto. 2015. Belajar \& faktor yang mempengaruhinya. Rineka Cipta, Jakarta.

Siregar E dkk. 2014. Teori Belajar dan Pembelajaran. Ghalia Indonesia, Bogor.

Sujarweni W. 2014. Metodologi penelitian. Pustaka Baru Press, Yogyakarta.

Sugiono. 2014. Metode penelitian kuantitatif, kualitatif, dan R\&D. Alfabeta, Bandung.

Sutanto A. 2014. Teori belajar dan pembelajaran di Sekolah Dasar. Prenda Media Group, Jakarta.

Wahyuni NM. 2015. Hubungan prestasi belajar nata pelajaran kewirausahaan dengan minat berwirausaha siswa SMKN 3 SINGARAJA. JPTK, UNIDIKSHA, Volume 12 Nomor 2.

Yustanto I dkk. 2011. Menggagas pendidikan islami. Al Azhar Press, Bogor. 